\title{
UPAYA PENINGKATAN KESEHATAN MASYARAKAT MELALUI PENGETAHUAN MENDETEKSI FORMALIN PADA DAGING AYAM DI KELURAHAN JAMBANGAN SURABAYA
}

\section{COMMUNITY HEALTH IMPROVEMENT EFFORTS THROUGH KNOWLEDGE OF DETECTING FORMALINES ON CHICKEN MEAT IN JAMBANGAN SURABAYA DISTRICT}

\author{
Jola Rahmahani \\ Fakultas Kedokteran Hewan \\ Wiwiek Tyasningsih \\ Fakultas Kedokteran Hewan
}

A. T. Soelih Estoepangestie

Fakultas Kedokteran Hewan

\begin{abstract}
ABSTRAK
Wilayah Kelurahan Jambangan Surabaya terdiri dari 29 RT dan 7 RW. Masyarakat Surabaya khususnya kelurahan Jambangan banyak memilih mengonsumsi daging ayam dibandingkan dengan daging yang lain, karena selain mengandung gizi yang tinggi protein juga karena harganya murah sehingga terjangkau oleh masyarakat. Dewasa ini telah banyak beredar di masyarakat adanya penggunaan formalin pada daging ayam untuk pengawetan supaya daging tidak mudah busuk, namun masih banyak masyarakat yang belum mengetahui bahayanya terhadap kesehatan. Pengabdian kepada Masyarakat ini bertujuan untuk memberdayakan masyarakat khususnya ibu-ibu anggota PKK melalui pengetahuan mendeteksi formalin pada daging ayam, yang difokuskan pada pengetahuan masyarakat dalam mengenal formalin dan bahayanya terhadap kesehatan. Hasil Pengabdian kepada Masyarakat menunjukkan bahwa ada peningkatan pemahaman ibu-ibu PKK di Kelurahan Jambangan Surabaya didalam mengenal formalin dan bahayanya terhadap kesehatan serta mengenal bagaimana daging ayam yang aman, sehat, utuh dan halal (ASUH).
\end{abstract}

Kata kunci: Kesehatan masyarakat, Formalin, Daging ayam

\section{ABSTRACT}

The area of Surabaya Jambangan Village consists of 29 RTs and 7 RWs. The people of Surabaya, especially the Jambangan village, prefer to consume chicken meat compared to other meats, because in addition to containing high protein nutrients as well because the price is cheap so it is affordable by the public. Today many people have circulated in the community the use of formaldehyde in chicken meat for preservation so that meat is not easily decayed, but there are still many people who do not know the dangers of health. Community Service aims to empower the community, especially mothers of PKK members through the knowledge of detecting formaldehyde in chicken meat, which focuses on the knowledge of the community in recognizing formalin and the dangers to health. Community Service Results showed that there was an increase in understanding of PKK mothers in Jambangan Surabaya Village in recognizing formalin and the dangers to health and knowing how safe, healthy, whole and halal chicken meat (ASUH).

Keywords: Public health, Formalin, Chicken meat

\section{PENDAHULUAN}

Kelurahan Jambangan, Kecamatan Jambangan, Kotamadya Surabaya merupakan wilayah Surabaya selatan yang merupakan wilayah padat penduduk dengan jumlah penduduk sekitar 10.071 jiwa dan luas wilayah sekitar 7.8 Ha (BPS, 2015).
Pertumbuhan ekonomi Indonesia dan penduduk yang semakin meningkat maka kebutuhan daging ayam juga meningkat karena untuk mencukupi kebutuhan bahan pangan sumber protein khususnya protein hewani. Sejak beberapa tahun yang lalu diketahui beberapa pedagang daging ayam telah melakukan penyalahgunaan bahan-bahan 
tambahan lainnya yang sebenarnya bukan untuk bahan tambahan makanan. Salah satu bahan tambahan makanan yang digunakan adalah formalin. Sebenarnya penggunaan bahan tambahan makanan sudah diatur didalam peraturan pemerintah PP nomor 28 tahun 2004 tentang Keamanan, Mutu dan Gizi Pangan.

Formalin yang mempunyai nama dagang larutan formaldehida termasuk golongan senyawa desinfektan kuat banyak digunakan oleh para pedagang daging ayam karena dapat membunuh berbagai macam bakteri pembusuk. Formaldehida mudah larut dalam air, sangat reaktif pada suasana alkalis dan tidak berwarna. Formaldehida biasanya mengandung alkohol sebanyak 10-15\% yang berfungsi sebagai stabilisator sehingga formaldehidanya tidak mengalami polimerisasi. Uap formalin yang terkontak langsung akan menyebabkan iritasi mata, hidung, esofagus dan saluran pernafasan, sedangkan bila masuk ke dalam tubuh manusia bersama makanan dapat menyebabkan keracunan organ fungsional yang ditandai dengan sukar menelan nafsu makan berkurang, mual, diare, muntahmuntah dan pada tingkat yang lebih parah bersifat karsinogenik dan menyebabkan kematian.

Sampai saat ini banyak masyarakat terutama masyarakat yang tinggal di Kelurahan Jambangan Surabaya belum mengetahui kerugian yang diakibatkan oleh penggunaan formalin pada daging ayam yang dijual di pasar-pasar sehingga masih memerlukan pemberdayaan masyarakat dalam meningkatkan kualitas hidupnya melalui pengetahuan dalam mendeteksi adanya formalin pada daging ayam sehingga masyarakat benar-benar mendapat bahan makanan yang aman, dengan demikian kebutuhan protein hewani masyarakat dapat dipenuhi.

Pola pemikiran dan pendekatan ini akan dikembangkan oleh LPPM dan Fakultas Kedokteran Hewan Universitas Airlangga melalui pengabdian kepada masyarakat yang terfokus pada penanganan untuk meningkatkan kualitas hidup masyarakat khususnya masyarakat di Wilayah Kelurahan Jambangan Surabaya untuk mendapatkan daging ayam yang aman dengan pengetahuan mendeteksi adanya formalin pada daging ayam yang dijual di pasaran.

\section{MATERI DAN METODE}

Pengabdian kepada Masyarakat dilakukan penyuluhan dan diskusi di Kelurahan Jambangan Surabaya pada tanggal 15 Oktober 2017. Khalayak sasaran adalah ibu PKK dan ibu rumah tangga di Kelurahan Jambangan Kotamadya Surabaya sebanyak 105 orang. Pendekatan metode yang digunakan dalam pengabdian kepada masyarakat ini adalah:

1. Penyuluhan

2. Demontrasi
Penyuluhan bersifat umum dan khusus yaitu tentang daging ayam yang aman, sehat, utuh dan halal (ASUH), formalin, bahayanya formalin pada kesehatan masyarakat. Sedangkan pada demonstrasi ditunjukkan tentang cara memilih daging ayam yang segar, daging ayam yang ditambahkan formalin dan cara melakukan deteksi formalin pada daging ayam dengan menggunakan Kit Formalin ET (Easy Test).

Data yang diperoleh berupa nilai dari hasil pretest dan posttest dari beberapa peserta yaitu ibu-ibu PKK Kelurahan Jambangan Surabaya yang mengikuti acara ini, Data diambil dari nilai yang dikumpulkan sebelum dilakukan penyuluhan dan sesudah dilakukan penyuluhan dengan menjawab pertanyaan yang diberikan. Selanjutnya data yang diperoleh ditabulasi kemudian dihitung persentase dan dianalis secara deskriptif.

\section{HASIL DAN PEMBAHASAN}

Pengabdian kepada masyarakat dengan judul "Upaya Peningkatan Kesehatan Masyarakat Melalui Pengetahuan Mendeteksi Formalin Pada Daging Ayam Di Kelurahan Jambangan Surabaya" yang dilaksanakan oleh Fakultas Kedokteran Hewan Universitas Airlangga sangat menarik bagi masyarakat khususnya ibu-ibu PKK Kelurahan Jambangan Surabaya. Hal ini terbukti dari prosentase kehadiran peserta untuk mengikuti acara tersebut. Dari peserta yang ditargetkan 40 orang, ternyata yang hadir sebanyak 65 orang, sehingga ada peningkatan sebanyak $65 \%$. Selain materi yang menarik dan dikarenakan saat ini banyak diduga beredar tambahan bahan formalin pada makanan yang telah beritakan oleh media cetak maupun media elektronik.

Tabel dibawah ini menunjukkan adanya peningkatan pengetahuan masyarakat terhadap materi yang diberikan oleh tim pengabdian kepada masyarakat yaitu berupa nilai hasil pretest dan post test dari beberapa peserta yang dipilih secara acak.

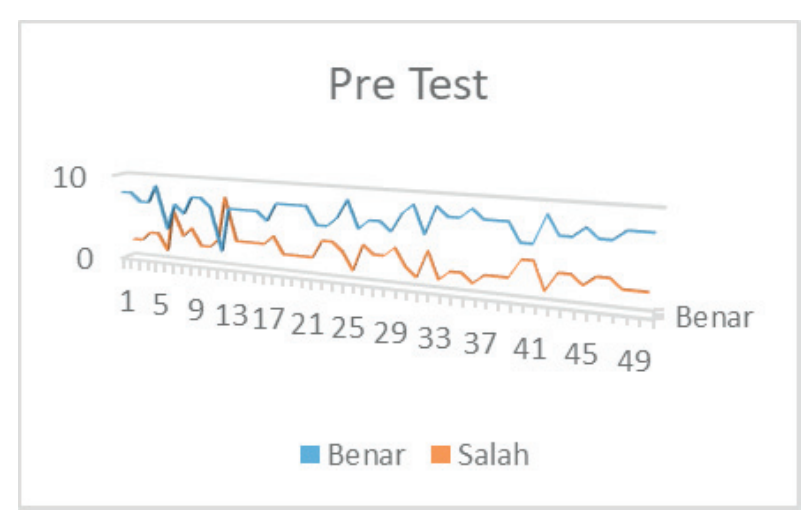


Rerata Peningkatan Pengetahuan Peserta pada Pre dan Post test terhadap Materi Yang Diberikan

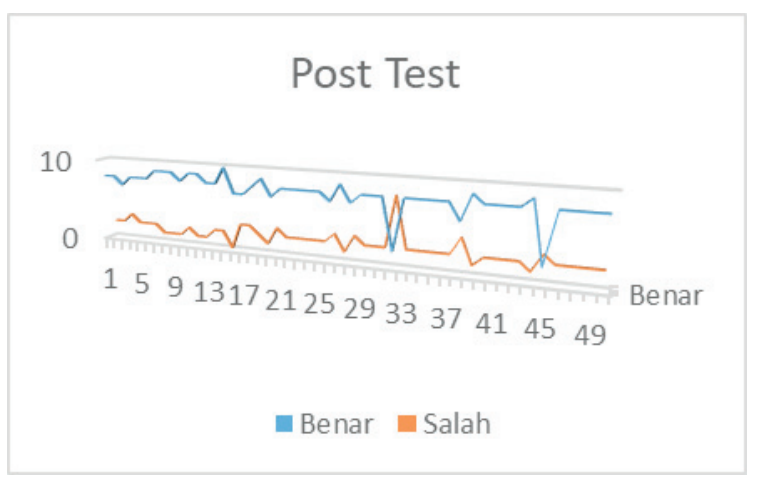

Nilai pre test dan post test yang diperoleh peserta pada pengabdian masyarakat tidak homogen, perbedaan nilai kemungkinan disebabkan karena tingkat pendidikan yang tidak sama yaitu mulai dari tingkat Sekolah Menengah Pertama (SMP) hingga Perguruan Tinggi (P T). Nilai pre test sudah lumayan bagus mungkin dikarenakan ibu-ibu sudah tahu sebelumnya tentang cara memilih ayam yang baik dan tidak berformalin dari media cetak maupun media elektronik. Secara keseluruhan terjadi peningkatan pengetahuan dan pemahaman para peserta setelah mendapat penyuluhan dan demonstrasi dari tim pengabdian kepada masyarakat, antara sebelum dan setelah penyuluhan rata-rata peningkatan pengetahuan tentang cara memilih daging ayam yang baik dan adanya penambahan formalin pada daging ayam dan bahayanya terhadap kesehatan sebesar $10 \%$.

Terkait dengan maraknya berita adanya penambahan bahan -bahan berbahaya pada bahan pangan seperti daging ayam dengan tujuan pengawetan pada bahan pangan masyarakat khususnya di Kelurahan Jambangan Surabaya sudah cukup baik mengetahui, hal ini terbukti dari hasil tes setelah dilakukan penyuluhan mendapatkan nilai ratarata diatas 70 , artinya paling tidak terhadap permasalahan tersebut pengetahuan dan kemampuan masyarakat sudah baik. Dengan demikian tujuan dan harapan dari pelaksanaan pengabdian kepada masyarakat untuk pemberdayaan masyarakat melalui deteksi formalin pada bahan pangan dalam hal ini daging ayam dan bahayanya terhadap kesehatan dapat dikatakan berhasil dengan harapan masyarakat khususnya ibu-ibu PKK di Kelurahan Jambangan dapat meningkatkan kualitas hidupnya dari bidang kesehatan.

\section{KESIMPULAN}

Berdasarkan hasil penyuluhan, demonstrasi dan hasil pengujian pengetahuan peserta pengabdian kepada masyarakat, dapat disimpulkan sebagai berikut:
1. Terdapat peningkatan pengetahuan peserta pengabdian kepada masyarakat terhadap daging ayam yang aman, sehat, utuh dan halal (ASUH)

2. Terdapat peningkatan pengetahuan peserta pengabdian kepada masyarakat terhadap formalin dan bahayanya terhadap kesehatan.

3. Terdapat peningkatan pengetahuan peserta pengabdian kepada masyarakat terhadap cara mendeteksi berformalin pada daging ayam.

\section{UCAPAN TERIMA KASIH}

Penulis mengucapkan terima kasih kepada Rektor Unair, Ketua LP4M Unair, serta Dekan Fakultas Kedokteran Hewan Unair yang telah memberikan pendanaan pada program pengabdian masyarakat, Bantuan Pendanaan Perguruan Tinggi Negeri (BPPTNBH) Universitas Airlangga sesuai surat keputusan Rektor Nomor : 1127/UN3/2017 Tanggal 11 Agustus 2017.

\section{DAFTAR PUSTAKA}

Arifin, Z., T. B. Murdiati dan R. Firmansyah. 2005. Deteksi Formalin Dalam Ayam Broiler di Pasaran. Seminar Nasional Teknologi Peternakan dan Veteriner. Bogor.

Badan Pusat Statistik. 2015. Data Statistik Penduduk Kota Surabaya.

Evy. 2004. Ikan asin di Sukabumi mengandung formalin. Kompas 20 Maret 2014.

Handayani. 2006. Bahaya Kandungan Formalin pada Makanan. Klinik PT Astra, International TBK- Head Office. Jakarta.

Rahmadani, E. F. 2008. Deteksi Daging Ayam Yang Diformalin Secara Visual, Organoleptik, Kimia dan Fisika. Skripsi. Teknologi Hasil Pertanian. Fakultas Pertanian. Universitas Sumatera Utara.

Ramidi. 2004. Makanan mengandung pengawet mayat beredar di Jakarta. Koran Tempoi, 3 April 2004.

Scheuplein, R.J. 1985. Formaldehyde, the Food and Drug Administration's perspective In. TuroskiVed Formaldehyde American Chemical Society. pp. 237 245 (Advences in Chemistry Series 210).

Setiowati, E. W dan Mardiastuti I. S. 2009. Tinjauan Bahan pangan Asal Hewan yang ASUH Berdasarkan Aspek Mikrobiologi di DKI Jakarta. Prosiding PPI Standardisasi 2009. Jakarta.

Yuliarti, Nurheti. 2007. Awas Bahaya diBalik Lezatnya Makanan. Yogyakarta: ANDI Yogyakarta. 